\section{Features of Roman plaster aggregates in Lombardy, Italy}

\author{
Roberto Bugini, Luisa Folli \\ Consiglio Nazionale delle Ricerche - \\ CNR, Istituto per la Conservazione e la \\ Valorizzazione dei Beni Culturali, Milano, \\ Italy
}

\section{Abstract}

Plaster making was reported in the seventh book of Vitruvius' On Architecture describing two mortar coats: harenatum with sand for the bottom (render coat) and marmoratum with crushed marble for the top (finish coat). Petrographic analyses, with optical microscopy and X-ray diffraction, were made on plasters ( $2^{\text {nd }}$ century BC $-4^{\text {th }}$ century $\mathrm{AD}$ ) coming from different roman sites of Lombardy: Milan, Brescia, Camonica valley, lake Garda, river Po plain. The analyses identified the plaster aggregates on the basis of composition, grain size and morphology. The render coats generally show river sand and/or crushed brick with some mineralogical differences due to the different supply areas. The finish coats show different types of aggregate: i) carbonate rocks (limestone, dolomite); ii) quartz crystals; iii) calcite crystals; iv) sand (quartz and silicates crystals and/or limestone clasts); v) sand and crushed brick. These differences can be useful to discriminate the changes among the time periods and among the sites.

\section{Introduction}

The scientific knowledge of the features of Roman plasters is an important step to discriminate the ancient artifacts and the changes in the making technique during the centuries (Béarat, 1996; Béarat et al., 1997; Baraldi et al., 2006). The making of the plaster was reported in Vitruvius' On Architecture ( $1^{\text {st }}$ century BC) (Vitruvius, 1931) and in Pliny the Elder's Naturalis Historia $\left(1^{\text {st }}\right.$ century AD) (Pliny the Elder, 1962). The Latin Authors describe the preparation of lime and the selection of aggregate, preparation of mortar, putting of different coats on the walls, precautions in damp places and pigments useful for the wall paintings.

The archaeological excavations, carried out by the Soprintendenza Archeologica della Lombardia in the last twenty years on Roman sites (towns, villages, suburban villas) in the Lombard territory, discovered a large number of walls coated by painted plasters: these plas- ters date back from the $2^{\text {nd }}$ century $\mathrm{BC}$ to the $4^{\text {th }}$ century $\mathrm{AD}$. In many cases the plaster was found as fragments from rubble, but in some cases the plaster still remains in situ on the original wall (Mariani et al., 2005).

\section{Materials and Methods}

The fragments were grouped before the sampling on the basis of macroscopic features (thickness, grains size, etc.) and on the basis of painting themes, so the sampled fragments are representative of the whole fragments unearthed in each site.

A series of scientific analyses was carried out on about 160 plaster samples. The methods employed are: optical microscopy on thin section for the aggregate mineralogy and texture, X-ray diffraction for the binder composition and the decay by-products. The choice of these traditional methods, in this case, comes from the need to analyse, saving time and money, a high number of samples according to the great variability of plaster compositions.

\section{Archaeological sites}

Milan, Mediolanum (region XI)

a-Necropolis in the area of Catholic University ( $1^{\text {st }-2^{\text {nd }}}$ century AD) (Lusuardi, 1987)

b-Domus found under a building, Cesare Correnti 24 street (2nd century AD) (Pagani, 2004)

c-Domus found under the paving, Meda square $\left(1^{\text {st }} 4^{\text {th }}\right.$ century $\left.\mathrm{AD}\right)$

d-Domus found under a building, Fontana square ( $1^{\text {st }}$ century $\left.\mathrm{AD}\right)$ (Ceresa Mori et al., 2007)

All the plasters come from rubble.

Brescia, Brixia (region X)

a-Fourth cell of the republican Sanctuary under the Capitolium ( $1^{\text {st }}$ century BC) (Rossi, 2002)

b-Excavation under the Sanctuary $\left(2^{\text {nd }}\right.$ century BC) (Mariani, 1996c)

c-Domus found under Silva palace, Trieste street ( $1^{\text {st }}-2^{\text {nd }}$ century AD) (Mariani, 1996b) d-Domus under Martinengo-Cesaresco palace, del Foro square $\left(1^{\text {st }}-2^{\text {nd }}\right.$ century $\mathrm{AD}$ ) (Mariani, 1996a)

e-Domus under Liceo Arnaldo, Magenta Avenue (1 ${ }^{\text {st }}$ century AD) (Pagani, 1996)

f-Domus under St Giulia monastery, Musei street $\left(1^{\text {st }} 4^{\text {th }}\right.$ century AD) (Mariani and Pagani, 2005)

The plaster from the site a) are still in situ; the plasters of the sites b-f) come from rubble.

Cividate Camuno (Brescia), Civitas Camunnorum (region X)

a-Domus under a medieval building, Palazzo street $\left(1^{\text {st }}\right.$ century $\left.\mathrm{AD}\right)$ (Mariani, personal communication)
Correspondence: Roberto Bugini, Consiglio Nazionale delle Ricerche - CNR, Istituto per la Conservazione e la Valorizzazione dei Beni Culturali, via Cozzi 53, 20125 Milano, Italy. Tel. +39.02.66173326 - Fax: +39.02.66173296. E-mail: bugini@icvbc.cnr.it

Key words: Roman plaster, aggregate, petrographic analyses.

Citation: Bugini R, Folli L, 2013. Features of Roman plaster aggregates in Lombardy, Italy. In: RH Tykot (ed.), Proceedings of the $38^{\text {th }}$ International Symposium on Archaeometry - May $10^{\text {th }}-14^{\text {th }} 2010$, Tampa, Florida. Open Journal of Archaeometry 1:e20.

Presented at the $38^{\text {th }}$ International Symposium on Archaeometry - May $10^{\text {th }}-14^{\text {th }} 2010$, Tampa, Florida.

(C) Copyright R. Bugini and L. Folli., 2013 Licensee PAGEPress, Italy

Open Journal of Archaeometry 2013; 1:e20 doi:10.4081/arc.2013.e20

b-Theatre ( $1^{\text {st }}$ century AD) (Mariotti, 2004) c-Amphitheatre ( $1^{\text {st }}$ century AD) (Mariotti, 2004)

The plasters of the site a) come from rubble, the plaster from the sites b-c) are in situ Breno (Brescia), Civitas Camunnorum Cells of the Minerva Sanctuary ( $1^{\text {st }}$ century AD), in situ (Mariani, 2010; Bianchi, 2010) Sirmione (Brescia), Sirmio (region X) Villa called Grotte di Catullo ( $2^{\text {nd }}$ century AD), from rubble (Roffia et al., 2005)

Calvatone - Costa di S. Andrea (Cremona), Bedriacum (region $\mathrm{X}$ )

a-Several unidentified domus $\left(1^{\text {st }} 2^{\text {nd }}\right.$ century AD) (Sena Chiesa, 1998)

b-Well in the Mirabella Roberti Area $7\left(1^{\text {st }}\right.$ century AD) (Mariani, 1997)

All the plasters come from rubble.

\section{Results}

Different features were detected in plasters coming from the same site: this difference is caused by finding plaster fragments in rubble layers. These layers were often arranged as insulation material to avoid the rise of the dampness in the walls of new buildings and they contain mixed materials (plaster, stone, terracotta, etc.) of indeterminate provenance.

The plasters are almost always made of two superimposed coats, indicated as render coat (close to the masonry) and finish coat (supporting the painted layer). Plasters from Milano, Brescia and Cividate (indicated as Milano-a,-c; Brescia-c,-e,-f; Cividate-c) show in some cases the presence of three coats: the 
intermerdiate coat has the same features, regarding the binder and the aggregate, of the render coat. In other cases (Milano-a,-b; Brescia-c;-f; Calvatone-a,-b) the rear surface of the render coat has strong marks of reeds with crosswise bindings: this kind of support is linked to the ceilings, but no differences were found in the ceiling plasters in regard to the wall plasters.

The analytical results pointed out the great variety of the aggregates on the basis of composition, grain size and morphology.

\section{Binder}

Magnesian lime (Magnesium carbonate magnesite, detected by X-ray diffraction) (Bugini et al., 1991) is used in the majority of the examined samples. The binder texture can be homogeneous or unhomogeneous (with white lumps) also in the same group of plasters.

\section{Plaster aggregate and layers}

Features of the aggregate are different which is very significant for the plaster classification, even more so when the number of plaster samples examined will be extended to all roman sites in Lombardy. The first noticeable feature is the silicate composition of the render coats and the carbonate composition in the finish coats. With very few exceptions, this subdivision matches, the quotations of Vitruvius' De Architectura (Vitruvius, 1931) where the composition of the aggregate was reported in chapters 3 and 4 of the seventh book. The Latin author describes two series of mortar coats each with its own aggregate: river sand and crushed brick (harenatum, for render coats) in different proportions and according to the environmental conditions (dry or damp places); crushed marble (marmoratum, for fin- ish coats) with different grain size. The sampled plasters show one or two render coats and only one finish coat instead of the three plus three coats described by Vitruvius.

\section{Aggregate composition}

The following list contains the petrographic compositions detected in each site: the first line (italics) is referred to the render coat; the second line is referred to the finish coat. In many cases two kinds of finish coat aggregate correspond to only one kind of render coat aggregate.

Milano- $a$. RENDER: quartz-gneiss sand and crushed brick (size 0.5-4 mm).

Milano-a. FINISH: i) calcite crystals (size 0.1$2.5 \mathrm{~mm}$ ), ii) quartz sand (size 0.1-2 mm).

Milano-b. RENDER: quartz-limestone sand with crushed brick (0.2-4 mm).

Milano-b. FINISH: i) quartz-limestone sand with crushed brick $(0.2-1 \mathrm{~mm})$; ii) calcite crystals and marble (0.1-2 mm).

Milano-c. RENDER: i) quartz-gneiss sand (0.2$0.4 \mathrm{~mm}$ ), ii) quartz-gneiss sand with brick (0.4$3 \mathrm{~mm})$.

Milano-c. FINISH: i) quartz-limestone-gneiss sand $(0.6-4 \mathrm{~mm})$, ii) calcite crystals $(0 .-0.6 \mathrm{~mm})$, iii) quartz crystals $(0.4 \mathrm{~mm})$.

Milano- $d$. RENDER: quartz-limestone-gneiss sand (0.5-5 mm).

Milano-d. FINISH: i) quartz crystals (0.1-3 $\mathrm{mm})$, ii) quartz-gneiss sand (1-3 mm).

Brescia- $a$. RENDER: quartz-limestone-dolomite sand (0.5-5.5 mm).

Brescia-a. FINISH: crushed dolomite (0.1-3 $\mathrm{mm})$.

Brescia- $b$. RENDER: limestone-quartz- gneiss sand $(0.2-0.4 \mathrm{~mm})$.

Brescia-b. FINISH: limestone-quartz- gneiss sand (0.2-0.4 mm).

Brescia-c. RENDER: limestone-quartz-gneiss sand $(0.4-3 \mathrm{~mm})$.
Brescia-c. FINISH: calcite crystals (0.1-1.5 $\mathrm{mm})$.

Brescia-d. RENDER: limestone-quartz-gneiss sand with crushed brick (0.3-4 mm).

Brescia-d. FINISH: crushed dolomite (0.1- 4 $\mathrm{mm})$.

Brescia-e. RENDER: i) quartz-gneiss sand (0.4$3 \mathrm{~mm})$; ii) crushed dolomite $(0.5-5 \mathrm{~mm})$.

Brescia-e. FINISH: crushed dolomite (0.5-1.5 $\mathrm{mm})$.

Brescia-f. RENDER: i) quartz-limestone sand with crushed brick $(0.4-3 \mathrm{~mm})$; ii) quartzgneiss sand $(0.2-3.5 \mathrm{~mm})$.

Brescia-f. FINISH: crushed dolomite $(0.2-2$ $\mathrm{mm})$.

Cividate-a. RENDER: quartz-limestone-gneiss sand $(0.2-4 \mathrm{~mm})$.

Cividate-a. FINISH: calcite crystals (quartzgneiss sand) (0.1-2 mm).

Cividate- $b$. RENDER: quartz-limestone-gneiss sand with brick $(0.5-4 \mathrm{~mm})$.

Cividate-b. FINISH: i) calcite crystals (0.2-l $\mathrm{mm})$, ii) quartz-limestone sand (0.5-1).

Cividate-c. RENDER: quartz-limestone-gneiss sand (0.5-2 mm).

Cividate-c. FINISH: i) calcite-marble (0.1-2.5), ii) quartz-limestone sand (0.5-3).

Breno. RENDER: limestone-quartz-gneiss sand $(0.2-4 \mathrm{~mm})$.

Breno. FINISH: calcite crystals (quartz-gneiss sand) $(0.1-3.5 \mathrm{~mm})$.

Sirmione. RENDER: i) quartz-limestonedolomite sand $(0.2-2 \mathrm{~mm})$; ii) oolitic limestone (0.4-4 mm); iii) quartz-gneiss-limestonedolomite sand $(0.2-2 \mathrm{~mm})$.

Sirmione. FINISH: i) calcite crystals $(0.1-2$ $\mathrm{mm})$; ii) oolitic limestone $(0.2-0.6 \mathrm{~mm})$; iii) fossiliferous limestone $(0.2-1 \mathrm{~mm})$.

Calvatone- $a$. RENDER: i) quartz-limestone sand $(0.5-5 \mathrm{~mm})$; ii) quartz-gneiss sand with crushed brick $(0.5-5 \mathrm{~mm})$

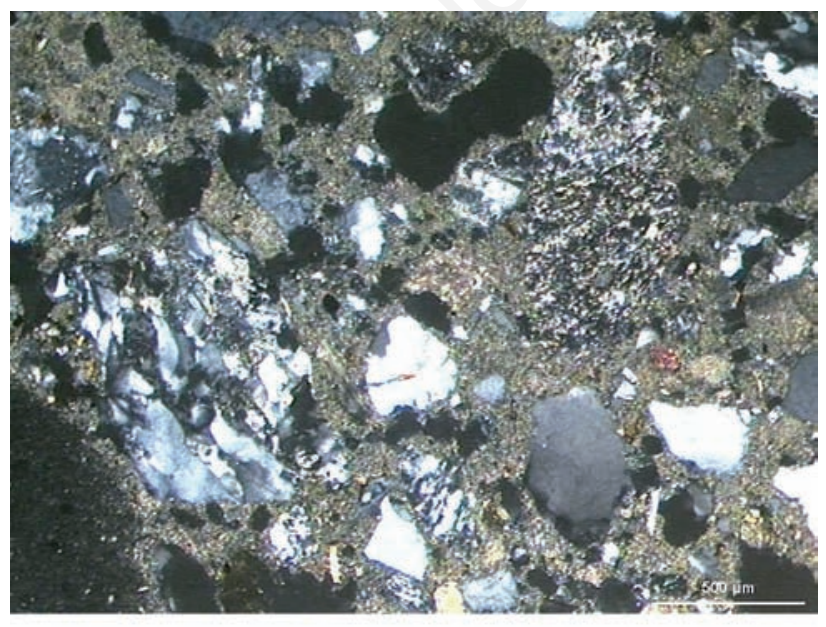

Figure 1. Milan-a, Catholic University, $1^{\text {st }}-2^{\text {nd }}$ century [thin-section, cross-polarised light (XPL)]. Render coat: aggregate made of metamorphic rocks clasts.

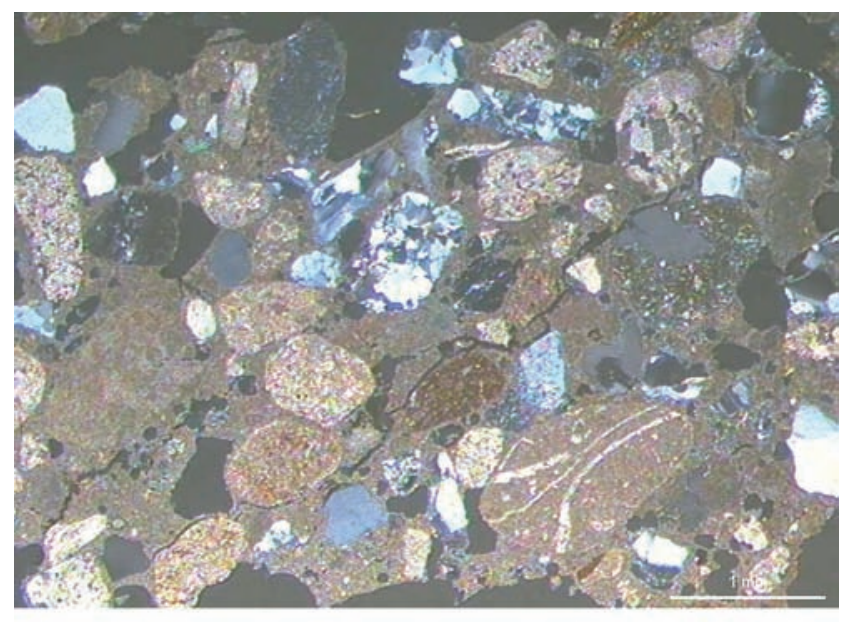

Figure 2. Calvatone-a, unidentified domus, $1^{\text {st }}-2^{\text {nd }}$ century [thinsection, cross-polarised light (XPL)]. Render coat: aggregate made mainly of rounded sedimentary rock clasts. 
Calvatone-a. FINISH: i) calcite crystals (0.2$0.8 \mathrm{~mm})$; ii) limestone sand (0.1-0.5 mm); iii) crushed brick (3-5 mm).

Calvatone- $b$. RENDER: limestone-quartz sand (0.2-3 mm).

Calvatone-b. FINISH: limestone-quartz sand (0.1-1 mm) with crushed brick (3-5 mm).

\section{Discussion}

The composition of the aggregate must be subdivided between the render and the finish coat, according to the difference reported by the Latin authors.

The render coats generally show a coarsegrained aggregate with some mineralogical differences and often an addition of brick fragments. The plasters of the western part of Lombardy (Milan; Figure 1) show a sandy aggregate made of metamorphic rocks clasts with rounded corners, coming from the sandy deposits of the Ticino river whose basin lays on the metamorphic and the igneous rocks of the Alps (mainly gneisses and granites). The plasters of the eastern part (Brescia and Cremona province; Figure 2) show a sandy aggregate made of sedimentary rocks clasts, coming from the sandy deposits of local rivers whose basins are laying on the sedimentary formations of the Prealps (mainly limestone and dolomites).

The finish coats are subdivided in five different groups, according to the aggregate composition. Three compositions are referred to crushed material: i) carbonate rock (limestone, dolomite) clasts (Figure 3); ii) quartz crystals; iii) calcite crystals (Figure 4). Two compositions are referred to sieved material: iv) sand (mainly quartz or calcareous or mixed); v) sand and brick fragments.

The use of a single mineral aggregate can be pointed out: quartz crystals (see point ii) or calcite crystals often called marble powder (see

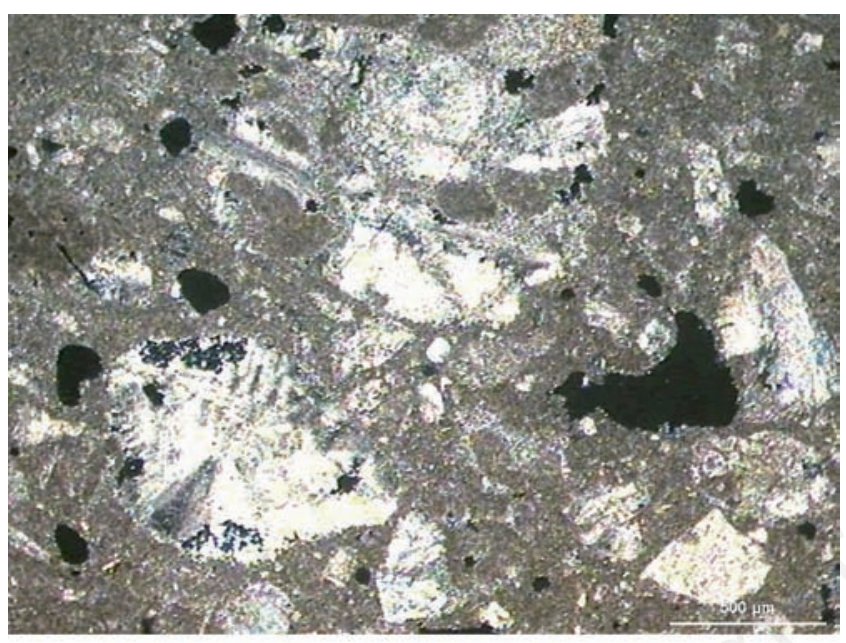

Figure 3. Sirmione, Villa, $2^{\text {nd }}$ century. Finish coat: aggregate made of fossiliferous limestone clasts [thin-section, crosspolarised light (XPL)].

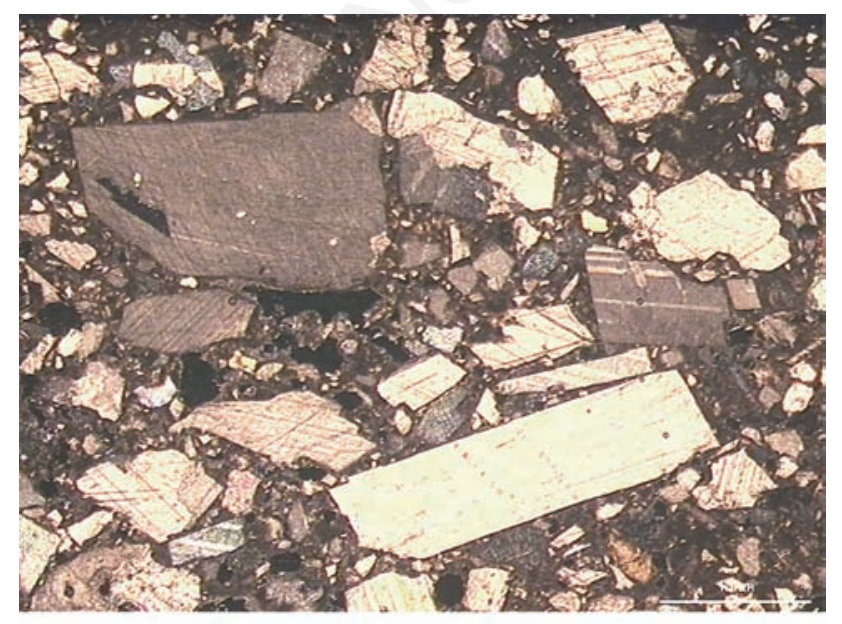

Figure 4. Cividate-a, Palazzo street, $1^{\text {st }}$ century [thin-section, cross-polarised light (XPL)]. Finish coat: aggregate made of crushed calcite crystals.

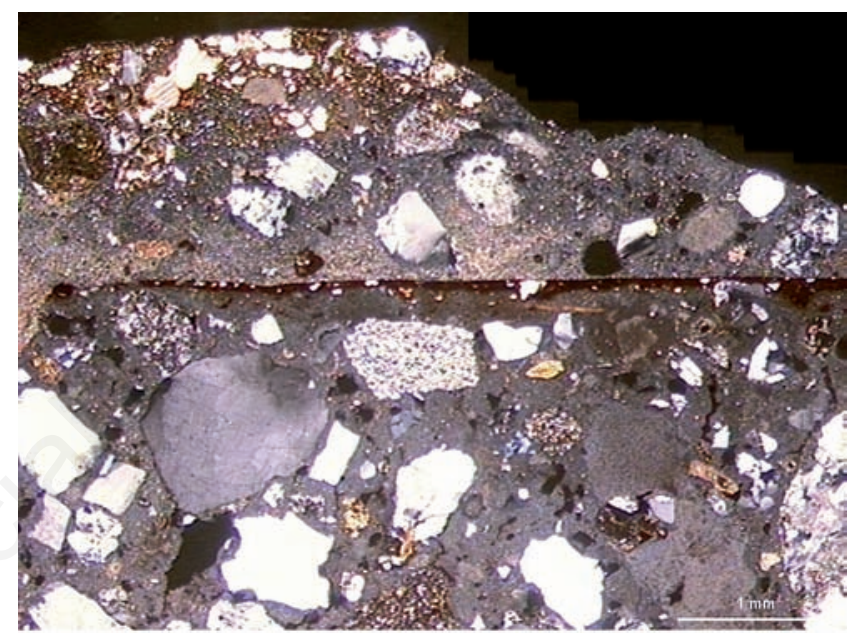

Figure 5. Milan-c, Meda square [thin-section, cross-polarised light (XPL)]. From bottom. Thick finish coat with metamorphic and calcareous clasts covered by a painted layer (early 1st century). Thin render coat with metamorphic clasts; thin finish coat with crushed calcite crystals covered by a painted layer (second half $1^{\text {st }}$ century).
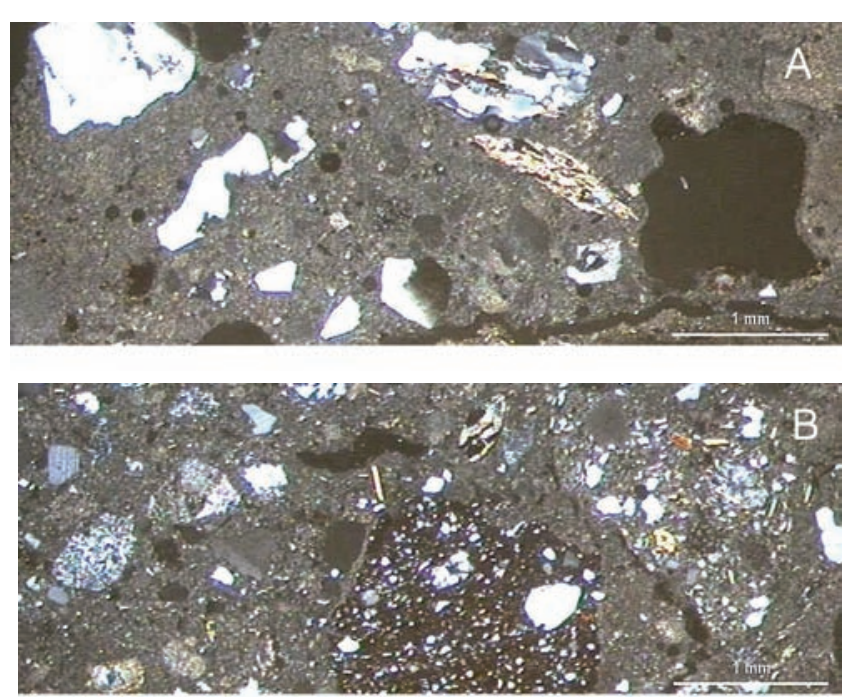

Figure 6. Milan-c, Meda square, first half 4th century [thin-section, cross-polarised light (XPL)]. A) Finish coat aggregate made of quartz crystals; B) render coat aggregate made of metamorphic clasts with crushed brick. 
point iii). Quartz is present in two different forms, always angular: polycrystalline agglomerates (maximum size $4.0 \mathrm{~mm}$ ) with wavy extinction, diffused in coarse grained aggregates; single crystals $(1.0 \mathrm{~mm})$, diffused in fine grained aggregates. These features are due to an artificial preparation of the aggregate, probably using as raw material the sand from the Ticino River.

Calcite too is present in two different forms, sometimes mixed together: sub-rounded polycrystalline agglomerates (maximum size 3.2 $\mathrm{mm}$ ) where each crystal shows cleavage lines and polysynthetic twinning; single crystals (3.5 $\mathrm{mm}$ ), bladed shape, sharp corners (rhombohedral cleavage), no twinning. These features are related to the crushing of two different raw materials: by-products of various marbles worked for sculpture or decorative purposes for polycrystalline agglomerates; calcite veins of the Mesozoic limestone formations (central Prealps) for single crystals.

\section{Conclusions}

The variability in the aggregate composition is useful as a discriminating factor for a chronological classification of the roman plasters in Lombardy, considering a change in the composition as a change in the period of application; these changes can be different in each site. Some examples support the validity of the use of the aggregate composition as discriminating factor. A sample from Piazza Meda (Milano-c) shows a double-coated plaster covering another double-coated plaster; both supporting a painted layer attesting their subsequent period of application: the older one (early $1^{\text {st }}$ century AD) shows a sand of metamorphic clasts with brick (render) and a sand of metamorphic and calcareous clasts (finish); the latter one (second half $1^{\text {st }}$ century AD) shows a sand of metamorphic clasts (render) and crushed crystals of calcite (finish) (Figure 5). Another plaster in the same site (first half $4^{\text {th }}$ century AD) shows a sand of metamorphic clasts with brick (render) and crystals of quartz (finish) (Figure 6). The use of different aggregate compositions in different sites seems to be linked rather to a specific choice of the mortar makers than to the raw material supply facilities: i.e. calcite crystals are widely used in the plasters of Calvatone, but the site is close to the River Po banks, made of quartz sands, and the first stone outcrop able to supply the calcite crystals is more than $50 \mathrm{~km}$ far.

\section{References}

Béarat H, 1996. Chemical and mineralogical analyses of Gallo-Roman wall painting from Dietikon, Switzerland. Archaeometry 38:81-95.

Béarat H, Fuchs M, Maggetti M, Paunier D, 1997. Roman wall painting. Materials, techniques, analysis and conservation. In: Proceedings International Workshop, Fribourg.

Baraldi P, Bonazzi A, Giordani N, Paccagnella F, Tannini P, 2006. Analytical characterization of roman plaster of the Domus Farini in Modena. Archaeometry 48:481-500.

Bianchi B, 2010. [La decorazione pittorica dei vani 2 e 5 e degli ambienti minori]. F. Rossi (ed.) [Il Santuario di Minerva: un luogo di culto a Breno]. [Book in Italian]. Milano, pp 223-49.

Bugini R, Toniolo L, Alessandrini G, Negrotti R, 1991. Characterization of plasters from the church of San Niccolò di Comelico (Belluno - Italy). Eur J Mineral 3:619-27.

Ceresa Mori A, Consonni D, Pagani C, 2007. [Milano piazza Fontana: indagini archeologiche]. Milano, pp 136-40.

Lusuardi S, Rossignani MP, 1987. [Milano Università Cattolica - Scavo nei cortili]. [Book in Italian]. Milano, pp 139-45.

Mariani E, 1996a. [Contributo preliminare sugli affreschi dagli edifici romani ritrovati sotto il palazzo Martinengo Cesaresco]. In: [CAL Carta Archeologica Lombardia - Brescia: la città]. [Book in Italian]. Modena, pp 157-64.

Mariani E, 1996b. [Contributo preliminare sugli affreschi ritrovati in via Trieste sotto il Credito Agrario Bresciano]. In: [CAL Carta Archeologica Lombardia - Brescia: la città]. [Book in Italian]. Modena, pp 13556.

Mariani E, 1996c. [Gli affreschi del saggio sotto il Santuario tardo-repubblicano]. In: [CAL Carta Archeologica Lombardia -
Brescia: la città]. [Book in Italian]. Modena, pp 131-4.

Mariani E, 1997. [Calvatone romana: un pozzo e il suo contesto - intonaci]. In: [Quaderni di ACME 29]. [Book in Italian]. Milano, pp 185-204.

Mariani E, 2010. [La decorazione pittorica del vano 1]. In: F. Rossi (ed.) [Il Santuario di Minerva: un luogo di culto a Breno]. [Book in Italian]. Milano, pp 205-22.

Mariani E, Pagani C, 2005. [Gli intonaci: considerazioni generali]. In: G.P. Brogiolo (ed.) [Dalle domus alla corte regia - Santa Giulia di Brescia]. [Book in Italian]. Firenze, pp 291-300.

Mariani E, Pagani C, Bugini R, Biondelli D, Naj $\mathrm{P}$, 2005. [Caratteri delle pitture murali romane in Lombardia. Compendio di dati analitici su malte e pigmenti]. In: [Atti del Convegno Scienza e Beni Culturali: sulle pitture murali]. [Proc. in Italian]. Venezia, pp 1147-59.

Mariotti V, 2004. [Il teatro e l'anfiteatro di Cividate Camuno: scavo, restauro e allestimento di un parco archeologico]. Firenze, pp 408.

Pagani C, 1996. [Liceo Arnaldo: gli intonaci dipinti]. In: [CAL Carta Archeologica Lombardia - Brescia: la città]. [Book in Italian]. Modena, pp 165-72.

Pagani C, 2004. [La decorazione parietale]. In: A. Ceresa Mori (ed.) [L'anfiteatro di Milano e il suo quartiere]. [Book in Italian]. Milano, pp 58-63.

Pliny the Elder, 1962. Naturalis Historia (translation by D. E. Eichholz). Cambridge.

Roffia E, Bugini R, Biondelli D, Folli L, 2005. [Le pitture murali della villa romana detta Grotte di Catullo (Sirmione)]. In: [Atti del Convegno Scienza e Beni Culturali: sulle pitture murali]. [Proc. in Italian]. Venezia, pp 755-61.

Rossi F, 2002. [Nuove ricerche sul Capitolium di Brescia: scavi, studi e restauri]. [Book in Italian]. Milano, pp 526.

Sena Chiesa G, 1998. [Calvatone: un vicus commerciale lungo la via Postumia]. In: [Atti del Convegno Postumia - storia e archeologia di una strada romana]. [Proc. in Italian]. Cremona, pp 345-67.

Vitruvius, 1931. De Architectura (translation by F. Granger). Harvard University Press; Cambridge. 